\title{
Trend and impact of plant cell publications: a bibliometric analysis of global research output from 1992 to 2016
}

\author{
Trang Ngoc Kieu Nguyen ${ }^{1}$ and Yuh-Shan $\mathrm{Ho}^{2 *}$ \\ ${ }^{1}$ Department of Biotechnology, College of Health Science, Asia University, 500 Lioufeng Road, Wufeng, Taichung 41354, Taiwan, China \\ 2 Trend Research Centre, Asia University, 500 Lioufeng Road, Wufeng, Taichung County 41354, Taiwan, China
}

\begin{abstract}
The objective of this writing was to conduct a bibliometric analysis of all plant cell publications during the period from 1992 to 2016 by using the Science Citation Index Expanded (SCI-EXPANDED) in the Clarivate Analytics Web of Science database. Basic analysis includes document types, languages, journals, Web of Science categories, distribution by countries and institutes. Indicators such as total, independent, collaborative, first author, corresponding author, and single author publications were applied to compare publication performances by specific countries and institutions of the top ranking. The G7 dominated most of the high impact publications in plant cell research. The high-ranked contributing institutions were non-universities from France, China, Russia, Spain, and USA. University of Tokyo in Japan was the most productive university single out on the top. Plant cell articles were published mainly in Web of Science of plant sciences. Plant Physiology, Plant Journal, and Plant Cell were the top three productive journals on this subject. In addition, top cited and the high impact articles in recent years were also compared. Distributions of words in title, author keywords, and KeyWords Plus in different periods were used for searching research focuses.
\end{abstract}

Keywords: plant cells; citations per publication; publication trends; Web of Science core collection; front page

* Correspondence to:

Yuh-Shan Ho, Trend Research Centre, Asia University, 500 Lioufeng Road, Wufeng, Taichung County 41354, Taiwan, China ; E-mail: ysho@ asia.edu.tw

Received: January 17, 2018; Accepted: February 7, 2018; Published Online: March 26, 2018

Citation: Nguyen, T.N.K. and Ho, Y.S., 2018, Trend and impact of plant cell publications: a bibliometric analysis of global research output from 1992 to 2016. Applied Environmental Biotechnology, 3(1), 10-20. http://doi.org/10.26789/AEB.2018.01.003.

Copyright: Trend and impact of plant cell publications: a bibliometric analysis of global research output from 1992 to 2016. @ 2018 Trang Ngoc Kieu Nguyen and Yuh-Shan Ho. This is an Open Access article distributed under the terms of the Creative Commons Attribution-Noncommercial 4.0 International License, permitting all non-commercial use, distribution, and reproduction in any medium, provided the original work is properly cited and acknowledged.

\section{Introduction}

Plants are unique among the eukaryotic organisms whose cells have membrane-enclosed nucleus and organelles (Adl et al., 2012). Plant cells are the basic unit of life in organisms of the Kingdom Plantae (Cavalier-Smith, 2009) and they are characteristic eukaryotic cells or cells with membrane bound nucleus (Pollard and Cooper, 2009). Plant cells are the basic building block and carry out all of the functions necessary for survival of the whole plant (Morant et al., 2007). The most important distinctive structure of plant cells is the presence of the cell wall outside the cell membrane (Cosgrove, 2005). Plant cells contain large central vacuoles (Neuhaus and Rogers, 1998). Vacuoles are related to lysosomes, which have specialized functions in assisting plant growth and playing an important structural role for the plant (Boller and Kende, 1979). Plant cells also contain chlorophyll, giving plants the green color and allows them to perform photosynthesis (van Kooten and Snel, 1990). Photosynthesis, the making of food from harvesting light as an energy, carbon dioxide, and water, occurs in the chloroplasts of the cell (Raghavendra et al., 1994).

Plant cells are relatively large and can differ considerably within a plant (Jin and Martin, 1999). There is a large diversity of different types of cells found through stems, leaves and roots (Stals and Inzé, 2001). They are separated into different types with different functions:

(1) Parenchyma cells, the majority of cells in a plant, are found in leaves and carry out photosynthesis and cellular respiration, along with other metabolic processes (Gunning and Pate, 1969).

(2) Collenchyma cells provide support to growing parts of a plant, they have thick cell walls, grow and change shape as a plant grows (Jones et al., 1997).

(3) Sclerenchyma cells, hard and tough, also have support function but in the areas of a plant that have ceased growing (Zhong and Zheng, 2007)

(4) Xylem cells transport mostly water and a few nutrients throughout a plant from the roots to the stem and leaves (Zwieniecki et al., 2001).

(5) Phloem cells transport nutrients made during photosynthesis to all parts of a plant. They transport sap, which is a watery solution high in sugars (Karley et al., 2002).

The history of plant cell researches is long but there were some important stages (Thorpe, 2007). In 1756, Henri-Louis Duhamel du Monceau pioneered the experiments on wound healing in plants through spontaneous callus formation on decorticated region of elm plants (Grasso, 1993). Prior to 1839 , the science of cell and tissue culture was advanced after proposing the cell theory by Schleiden and Schwann 
(Vasil, 2008). In 1908, Simon successfully regenerated a bulky callus, buds, roots from a poplar trees on the surface of medium containing indolic acetic acid (IAA), which plays regulatory role in cell division (Gautheret, 1983). From 1940 to 1970 , suitable nutrient media were developed for culturing plant cells, tissue, protoplasts, anthers, roots tips and embryos (Thorpe, 2007). Based on the success of plant cell culturing techniques, many recent advances had been made in the area of micropropagation, production of secondary metabolites and pathogen-free plants, genetic manipulation (Hussain et al., 2012). Plant cell and tissue culture are applied in medical, cultivation, food, biochemistry and others (Burton and Fincher, 2014; Mitani et al., 2017).

This data analysis was designed to determine the trends in articles devoted to plant cell from 1992 to 2016. The bibliometric research data were based on those available from Science Citation Index Expanded (SCI-EXPANDED). Trends in journals analysis, Web of Science category, nationally collaborative publication and author's keywords.

\section{Materials and Methods}

The data reported in this study were retrieved from the online version of Science Citation Index Expanded (SCI-EXPANDED), the Clarivate Analytics Web of Science Core Collection database (updated on October 30, 2017). Keywords "plant cells", "plant cell", "plant cellwalls", and "plant celle" were searched in terms of topic (including title, abstract, author keywords, and KeyWords Plus) within the publication years from 1992 to 2016. KeyWords Plus supplies additional search terms extracted from the titles of articles cited by authors in their bibliographies and footnotes in the ISI (now Clarivate Analytics) database, and substantially augments title-word and author-keyword indexing (Garfield, 1990a, b). This yielded 22,591 documents as plant cells-related publications for further analysis. Those documents can only be found in by KeyWords Plus are more likely to be unrelated to the "plant cells". In recent years, Ho's group firstly proposed the "front page" filter (Fu et al., 2012; Fu and Ho, 2014; Ho and Fu, 2016) - which covers only documents with searching keywords in their "front page", including only the title, abstract, and author keywords - might avoid introducing unrelated publications for analysis (Fu et al., 2012). Finally, 16,972 documents were defined as plant cells-related research publications. The full record of SCI-EXPANDED and the number of citations in each year for each document were downloaded into Microsoft Excel 2013 and additional coding manually performed (Li and Ho, 2008; Ho and $\mathrm{Fu}, 2016)$. The journal impact factors $\left(I F_{2016}\right)$ were taken from the Journal Citation Reports (JCR) published in 2016.

Affiliations of authors in England, Scotland, Northern Ireland, and Wales were re-grouped as one group by the United Kingdom (UK). Hong Kong before 1997 were included under the heading of China (Fu and Ho, 2013). Yugoslavia were checked and re-classified to Serbia (Wambu et al., 2017), Croatia, or Slovenia. USSR (the Union of Soviet Socialist Republics) were checked and re-classified as Russia (Ho et al., 2016), Ukraine (Wambu et al., 2017), Belarus, Tatarstan, Azerbaijan, or Latvia. Czechoslovakia were checked and re-classified to either Slovakia or Czech Republic (Lin and Ho, 2015). Similarly, Acad Sci USSR was checked and re-classified as being the Russian Acad Sci (Russian Academy of Sciences) and the Tatarstan Acad Sci (Tatarstan Academy of Sciences). Czechoslovak Acad Sci was checked and re-classified as being the Czech Acad
Sci. Minist Publ Hlth USSR was checked and reclassified as being the Minist Publ Hlth Russia.

Contributions of different institutions and countries were estimated by the affiliation of at least one author to the articles (Wang et al., 2010). Collaboration type was determined by the affiliations of the different authors, where the term 'single country article' $(S P)$ was assigned if all authors were from the same country. The term 'internationally collaborative article' $(C P)$ was designated to those articles that were co-authored by researchers from multiple countries. The term 'single institute article' $(S P)$ was assigned if the address of all authors was from a single institute. The term 'interinstitutionally collaborative article' $(C P)$ was assigned if authors were from different institutes.

To investigate the citations received by plant cell-related publications, indicators such as $C_{2016}, T C_{2016}$, and $C P P_{2016}$ were applied. The impact of papers in the most recent years is considered as the number of citations from Web of Science Core Collection of a paper in 2016 only, $C_{2016}$ (Ho, 2012); citations of papers are considered as the total number of citations since publication to the end of 2016 was referred to as $T C_{2016}$ (Wang et al., 2011; Chuang et al., 2011); and $C P P_{2016}$, citations per publication $\left(C P P_{2016}=T C_{2016} / T P\right)(\mathrm{Ho}$, 2012; Chuang and Ho, 2015).

\section{Results and Discussion}

\subsection{Document Type and Language of Publica- tion}

During the period examined, there were 16,972 plant cellrelated documents from 20 document types found. Article was the most-frequently used document type with 13,517 entries comprising $80 \%$ of the total publications. Distribution of document type about plant cell is shown in Table 1. Similar with other fields, review had $C P P_{2016}$ (citation per publication; $\left.C P P_{2016}=T C_{2016} / T P\right)$ higher than article (Ho and Fu, 2016; Wambu and Ho, 2016) because the former emphasizes on major development for each research topic and, as a result readers can read as well as understand easily for the contents for wide citations (Guimarães and Garlini, 2004). The results also recorded that document type of 'retracted publication' had highest citation per publication with $C P P_{2016}$ of 221, indicating the attractiveness of the research topic and issue in these publications. The retracted publication entitled "An enhanced transient expression system in plants based on suppression of gene silencing by the p19 protein of tomato bushy stunt virus" (Voinnet et al., 2003) with $T C_{2016}$ of 995 is one of a good example to reach the highest $C P P_{2016}$ in retracted publication in SCI-EXPANDED. This retracted publication was also corrected subsequently two times by the authors (Voinnet, 2015; Voinnet et al., 2015).

Journal articles were used for further analysis because they represented the majority of document types that also included whole the research hypothesis, methods and results (Ho et al., 2010). Thirteen languages were found and only one article was published in a multi-language journal. English $\left(13,306\right.$ articles; $98 \%$ of 13,$\left.517 ; C P P_{2016}=34\right)$ was the most used language, followed distantly by Russian $(60$; $\left.0.44 \% ; C P P_{2016}=1.8\right)$, Chinese $\left(33 ; 0.24 \% ; C P P_{2016}=\right.$ 
Table 1. Distribution of document type

\begin{tabular}{|c|c|c|c|c|c|c|}
\hline Document type & $T P(\%)$ & $T P^{*}$ & $A U$ & $A P P$ & $T C_{2016}$ & $C P P_{2016}$ \\
\hline Article & $13,517(80)$ & 13,507 & 67,350 & 5 & 446,702 & 33 \\
\hline Review & $2,611(15)$ & 2,611 & 7,715 & 3 & 168,041 & 64 \\
\hline Proceedings paper & $631(3.7)$ & 631 & 2,400 & 3.8 & 23,479 & 37 \\
\hline Meeting abstract & $448(2.6)$ & 443 & 1,827 & 4.1 & 81 & 0.18 \\
\hline Editorial material & $217(1.3)$ & 214 & 396 & 1.9 & 4,531 & 21 \\
\hline Book chapter & $155(0.91)$ & 155 & 486 & 3.1 & 11,548 & 75 \\
\hline Note & $73(0.43)$ & 73 & 265 & 3.6 & 1,634 & 22 \\
\hline Correction & $33(0.19)$ & 33 & 148 & 4.5 & 134 & 4.1 \\
\hline Letter & $28(0.16)$ & 28 & 79 & 2.8 & 691 & 25 \\
\hline News item & $22(0.13)$ & 14 & 17 & 1.2 & 152 & 6.9 \\
\hline Addition correction & $6(0.035)$ & 6 & 21 & 3.5 & 3 & 0.5 \\
\hline Biographical-item & $5(0.029)$ & 5 & 8 & 1.6 & 1 & 0.2 \\
\hline Retracted publication & $5(0.029)$ & 5 & 26 & 5.2 & 1,103 & 221 \\
\hline Reprint & $4(0.024)$ & 4 & 6 & 1.5 & 13 & 3.3 \\
\hline Book review & $3(0.018)$ & 3 & 3 & 1 & 0 & 0 \\
\hline Discussion & $1(0.0059)$ & 1 & 6 & 6 & 2 & 2 \\
\hline Hardware review & $1(0.0059)$ & 1 & 4 & 4 & 3 & 3 \\
\hline Item about an individual & $1(0.0059)$ & 1 & 1 & 1 & 0 & 0 \\
\hline Retraction & $1(0.0059)$ & 1 & 1 & 1 & 0 & 0 \\
\hline Software review & $1(0.0059)$ & 1 & 1 & 1 & 0 & 0 \\
\hline
\end{tabular}

$T P$ : total articles, $T P^{*}$ : total articles with authors' information in Web of Science; $A U$ : number of authors, $A P P$ : number of publication; $T C_{2016}$ : total citations since publication to the end of 2016; $C P P_{2016}$ : citations per publication $\left(T C_{2016} / T P\right)$

1.5), Polish (29; 0.21\%; $\left.C P P_{2016}=1.1\right)$, and German (17; $\left.0.13 \% ; C P P_{2016}=2.6\right)$. Others languages also used in plant cell-related studies, such as French (16 articles), Japanese (16), Portuguese (15), Spanish (12), Czech (9), and one for each of Finnish, Hungarian, and Korean, respectively.

\subsection{Characteristics of Publication Outputs}

In recent years, Ho's group proposed a relationship between total number of articles in a year $(T P)$ and their citations per publication $\left(C P P_{\text {year }}=T C_{\text {year }} / T P\right)$ by the years in a research field as a unique indicator (Chuang et al., 2012; Chuang and Ho, 2015). The annual number of SCI-EXPANDED articles including searching keywords in "front page" for the period examination counted and is displayed in Figure 1. The number of articles was fluctuated with an increase from 324 articles in 1992 to 556 articles in 2008 and another sharply increased from 2008 to 2016. Articles published in the period 1992-2008 had the highest $C P P_{2016}$. This is not surprising because newly published articles require time to accumulate citations (Picknett and Davis, 1999). The highest $C P P_{2016}$ was 58 in 2003, this attributed to the four of the top ten articles $\left(T C_{2016}>840\right)$ such as articles by Khvorova et al. (2003) $\left(T C_{2016}=1,446\right.$; ranked $\left.1^{s t}\right)$, Blokhina et al. (2003) $\left(T C_{2016}=1,393 ;\right.$ ranked $\left.2^{n d}\right)$, Foreman et al. (2003), $\left(T C_{2016}\right.$ = 1,078; ranked $3^{r d}$ ), and Voinnet et al. (2003) $\left(T C_{2016}=\right.$ 995; ranked $5^{\text {th }}$ ). Based on Figure 1, it takes CPPs about a decade to reach a plateau. Similarly, highly cited articles in Taiwan (Chuang and Ho, 2015) and articles published in Journal of Membrane Science (Fu and Ho, 2015) also took about one decade to reach a plateau. It might be concluded that to evaluate impact of papers, citations accumulated at least one decade is needed for a good assessment of their active life (Ho and Fu, 2016).

\subsection{Journals and Web of Science Categories}

In last decade, distribution of Web of Science categories and journals were investigated in research topics (Chiu and Ho, 2007). In total 13,517 plant cells-related articles were published in 1,557 journals in a range of 139 Web of Science categories in SCI-EXPANDED. Distribution of the top 11 productive journals, which published over 200 articles as listed in Table 2. Plant Physiology $\left(I F_{2016}=6.456\right)$ published the most articles with 612 articles (4.5\% of 13,517 articles), while Plant Journal ranked second with 507 articles $(3.8 \%)$. Eight of the eleven journals listed in the category of plant sciences. Journal of Biological Chemistry was the only one listed in category of biochemistry and molecular biology. Proceedings of the National Academy of Sciences of the United States of America and PLoS One were listed in category of multidisciplinary sciences. The percentages of leading journals with distribution of articles in plant cell research and other fields were not high (Zhang et al., 2010). Article entitled "Functional siRNAs and miRNAs exhibit strand bias" (Khvorova et al., 2003) published in Cell (IF 2016 $=30.410$ ) had the highest $T C_{2016}=1,446$ and $C_{2016}=76$ and become the most cited article in this field.

Plant science (5,734 articles), biochemistry and molecular biology $(3,389)$, biotechnology and applied microbiology $(1,843)$, cell biology $(1,635)$, multidisciplinary sciences (877), and microbiology (584) were the top six most popular categories. Comparison of the growth trends of Web of Science categories in a research field is proposed as Figure $1(\mathrm{Li}$ et al., 2009b). Publishing trends of the six most productive Web of Science categories in plant cell research are shown in Figure 2. The number of publications in the category of microbiology showed a steady growth without any sharp changes, while categories of plant science, biotechnology and applied microbiology, and multidisciplinary sciences showed a period of rapid growth over the last decade. In addition, publications in the category of microbiology might catch up cell biology in the next year based on further extrapolation from the current trend.

\subsection{Countries and Institutes}

Excluding 47 articles ( $0.35 \%$ of 13,517 articles) without any affiliation information of authors in Web of Science, there were 13,470 articles with author information. Altogether, 10,026 ( $74 \%$ of 13,470 articles) were single country articles and 3,444 (26\%) were internationally collaborative articles. The top ten countries, taking up $78 \%$ of the 13,470 articles, are listed in Table 3 with six indicators, such as total number of articles, single country articles, internationally collaborative articles, first author articles, corresponding author articles, and single author articles (Ho and Kahn, 2014) as well as $C P P_{2016}$. The G7 (United States of America, UK, 
Table 2. Top eleven productive journals.

\begin{tabular}{|c|c|c|c|}
\hline Journal & $T P(\%)$ & $I F_{2016}$ & Web of Science category \\
\hline Plant Physiology & $612(4.5)$ & 6.456 & Plant Sciences \\
\hline Plant Journal & $507(3.8)$ & 5.901 & Plant Sciences \\
\hline \multirow{3}{*}{ Plant Cell } & \multirow{3}{*}{$369(2.7)$} & \multirow{3}{*}{8.688} & $\begin{array}{c}\text { Biochemistry and Molecular } \\
\text { Biology }\end{array}$ \\
\hline & & & Plant Sciences \\
\hline & & & Cell Biology \\
\hline $\begin{array}{l}\text { Proceedings of the } \\
\text { National Academy of } \\
\text { Sciences of the United } \\
\text { States of America }\end{array}$ & $327(2.4)$ & 9.661 & Multidisciplinary Sciences \\
\hline PLoS One & $269(2)$ & 2.806 & Multidisciplinary Sciences \\
\hline Planta & $263(1.9)$ & 3.361 & Plant Sciences \\
\hline $\begin{array}{l}\text { Journal of Experimental } \\
\text { Rotanv }\end{array}$ & $258(1.9)$ & 5.83 & Plant Sciences \\
\hline $\begin{array}{l}\text { Journal of Biological } \\
\text { Chemistry }\end{array}$ & $254(1.9)$ & 4.125 & $\begin{array}{c}\text { Biochemistry and Molecular } \\
\text { Biology }\end{array}$ \\
\hline Plant and Cell Physiology & $239(1.8)$ & 4.76 & $\begin{array}{l}\text { Plant Sciences } \\
\text { Cell Biology }\end{array}$ \\
\hline \multirow{3}{*}{$\begin{array}{l}\text { Molecular Plant-Microbe } \\
\text { Interactions }\end{array}$} & \multirow{3}{*}{$224(1.7)$} & \multirow{3}{*}{4.332} & $\begin{array}{c}\text { Biochemistry and Molecular } \\
\text { Biology }\end{array}$ \\
\hline & & & $\begin{array}{c}\text { Biotechnology and Applied } \\
\text { Microbiology }\end{array}$ \\
\hline & & & Plant Sciences \\
\hline \multirow[t]{2}{*}{ Plant Molecular Biology } & \multirow[t]{2}{*}{$218(1.6)$} & \multirow[t]{2}{*}{3.356} & $\begin{array}{c}\text { Biochemistry and Molecular } \\
\text { Biology }\end{array}$ \\
\hline & & & Plant Sciences \\
\hline
\end{tabular}

$T P(\%)$ : rank and the percentage of number of articles; $I F_{2016}$ : impact factor in 2016

Germany, Canada, France, Japan, and Italy), China, Australia, and Spain were ranked the top ten. USA was the most dominant country producing 3,506 articles and ranked top in all six indicators. Japan ranked $2^{\text {nd }}$ for first author, and corresponding author articles separately while Germany ranked $2^{n} d$ in internationally collaborative, and the UK ranked $2^{\text {nd }}$ in single author articles. The G7 published 8,827 articles (66\% of the 13,470 articles with author-affiliation information) with $T C_{2016}$ of 355,040 (80\% of 445,104 citations) and $C P P_{2016}$ of 40 . Domination in publication output by mainstream countries was not surprising because similar pattern has been reported in research on, for example, photosynthesis (Yu et al., 2012), drinking water (Fu et al., 2013), and proteomics (Tan et al., 2014). UK had the highest $C P P_{2016}$ of 51, followed by USA (47) and Germany (42). China had much lower $C P P_{2016}$ of 16. Figure 3 illustrates the annual number of articles from the six most productive countries during 1992-2016. USA ranked the first place, showing a slightly growth from 2006 to 2014, while China had a dramatic increasing from 2004 to 2015, number of articles published in this period was getting higher from 26 to 168 and even higher

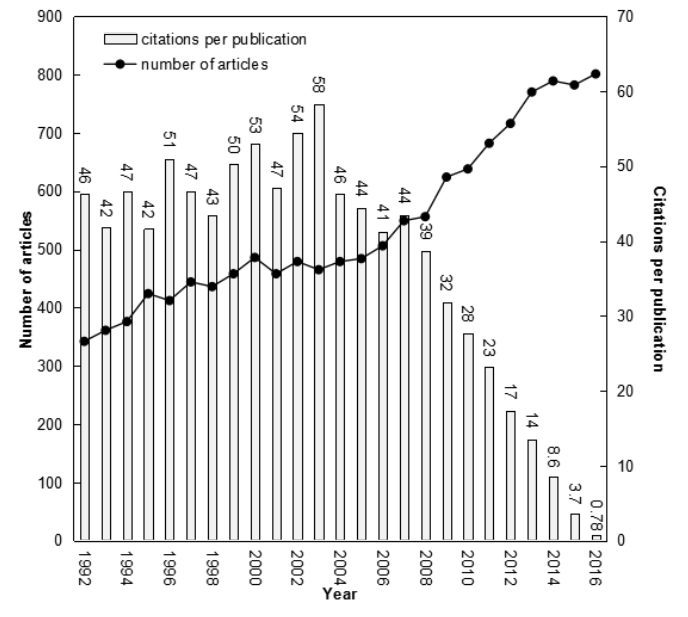

Figure 1. Number of articles and citations per publication by year in the research field of plant cell between 1992 and 2016.

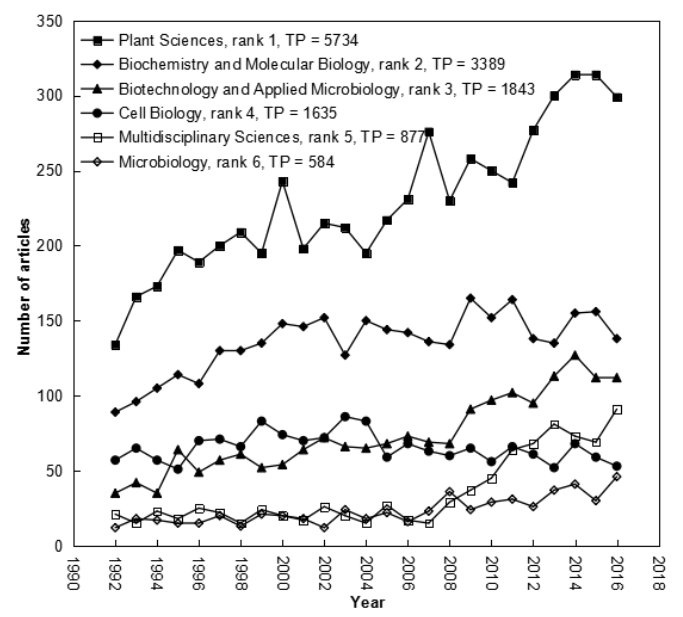

Figure 2. The top six Web of Science categories during 1992-2016.

than any other countries singularly. This indicates that China has made great progress and developed rapidly in plant cell research in the last decade.

Of the 13,470 articles with author affiliations in Web of Science, 6,164 (46\% of 13,470 articles) were single institution articles and 7,306 (54\%) were inter-institutionally collaborative articles. Six indicators such as number of total, independent, collaborative, first-author, corresponding-author, and single-author articles were proposed to evaluate publications by institutions and countries (Ho and Kahn, 2014). The top ten productive institutions are listed in Table 4 with these six indicators. Five of the ten top institutions were government research institutions. A bias in institute analysis should be noted that the National Institute of Agricultural Research (INRA) in France (Ho, 2014), the National Center for Scientific Research (CNRS) in France, the Chinese Academy of Sciences in China (Li et al., 2009b), the Russian Academy of Sciences in Russia (Li et al., 2009a), and the Spanish National Research Council (CSIC) (Elango and Ho, 2017) have many branches in different cities. The articles of these five in- 


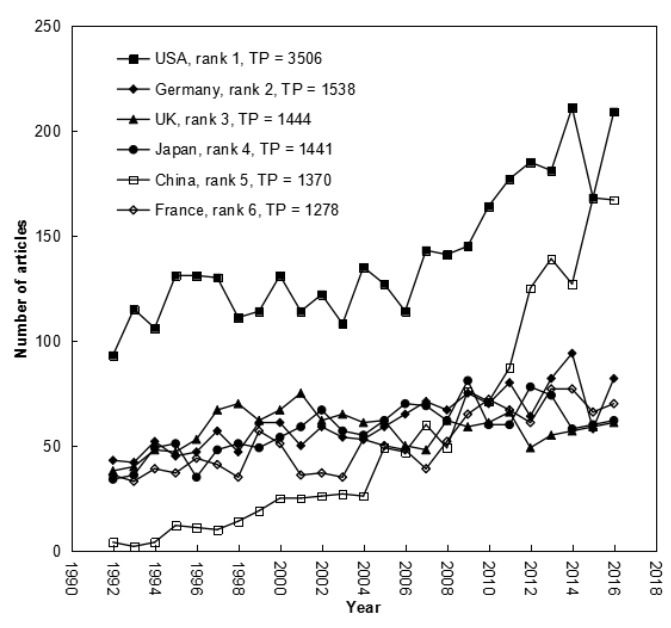

Figure 3. Trends of publications for the top six most productive countries in the research field of plant cell $(T P>1,000)$.

stitutes were pooled under one heading as mentioned in Web of Science respectively, but articles divided into branches would result in different rankings (Li et al., 2009b). INRA in France (303 articles; $2.2 \%$ of 13,470 articles) was the most productive institution, a public institute in French that dedicated to agricultural science. Five of the top ten institutes on plant cell research were universities such as University of Tokyo in Japan, Cornell University, Purdue University, University of California Berkeley, and University of Georgia in USA, respectively (Table 4). Similar, it was reported that four of the top ten institutes on photosynthesis research were universities and six were government research institutes (Yu et al., 2012). University of Tokyo in Japan and University of California Berkeley in USA ranked not only top ten on plant cell researches but also photosynthesis research (Yu et al., 2012).

\subsection{Top Cited Articles}

Ho (2012) proposed total number of citations since publication to the end of the most recent year $\left(C_{\text {year }}\right)$ and number of citations in the most recent year $\left(C_{\text {year }}\right)$ to compare with the top cited articles in the research fields. The top ten cited articles with $T C_{2016}$ and $C_{2016}$ in plant cell field is listed in Table 5. Cell $\left(I F_{2016}=30.41\right)$ was the only one journal published two highly cited articles. Other journals such as Advanced Functional Materials $\left(I F_{2016}=12.124\right)$, Annals of Botany $\left(I F_{2016}=4.041\right)$, Nature $\left(I_{2016}=40.137\right)$, Phytochemistry $\left(I F_{2016}=3.393\right)$, Plant Journal $\left(I F_{2016}=5.901\right)$, Science $\left(I F_{2016}=37.205\right)$, Current Biology $\left(I F_{2016}=8.851\right)$, and Journal of Experimental Botany $\left(I F_{2016}=5.830\right)$ published only one of the top ten articles respectively. USA dominated publications in the highly cited articles (50\%). Articles entitled "Engineered GFP as a vital reporter in plants" (Chiu et al., 1996) was the only one internationally collaborative article by USA and Japan. Six of the top ten highly cited articles $\left(T C_{2016}\right)$ can also be found in the top ten high impact articles in the most recent year $\left(C_{2016}\right)$. In pluripotent stem cell research, six of the top ten articles in $T C_{\text {year }}$ can be also found in the top ten in $C_{\text {year }}$ (Lin and Ho, 2015). In top ten most cited articles, only two published in 1990s. The most cited articles was "Functional siRNAs and miRNAs exhibit strand bias" (Khvorova et al., 2003) with $T C_{2016}$ of 1,446 and $\mathrm{C} 2016$ of 76 ranked in $13^{\text {th }}$ while the most impact article in the most recent year entitled "Breaking the code of DNA binding specificity of TAL-Type III effectors" (Boch et al., 2009) with C2016 of 196 and $T C_{2016}$ of 939 ranked in $6^{\text {th }}$. In this article, the authors showed how target DNA specificity of transcription activatorlike effectors from plant pathogenic is encoded and the new specificities of the modular protein architecture enabled the construction of artificial effectors (Boch et al., 2009).

A historical perspective of the eight highly cited articles with over 870 citations is shown in Figure 4. Two articles published in 1990s had a rapid increasing from the publishing year, but after several years, citation of these articles decreased and kept fluctuated to the end of the period examined in this analysis. Otherwise, two articles published in 2000 s with the most citations in $2016\left(C_{2016}\right)$ showed citations increased sharply and kept up to the end of period. It is clear from Figure 4 that the highly cited articles might not always maintain high impact or visibility after publication (Ho and Kahn, 2014).

\subsection{Hot Issues}

Word cluster which uses supporting words in title, abstract, author keywords, and KeyWords Plus to find the main research focuses and then research trends (Mao et al., 2010; Wang and Ho, 2016). This method can analyze the historical development of the science more completely and precisely, and more importantly, to discover the directions the science is taking (Chen and Ho, 2015; Zheng et al., 2017). Each word cluster was composed of several supporting words that include plural forms, abbreviations, and other transformations, as well as words with similar meaning from words in title, abstract, author keywords, and KeyWords Plus analysis results. Then the word cluster can also search combined words from abstract of the related publications. Finally, by analyzing the number of publications containing these "word clusters", the overview of the research hotspots could be revealed. For example, "Arabidopsis", "Arabidopsis thaliana", "Arabidopsis-thaliana", and "thaliana", constitute a word cluster for a research focus on Arabidopsis, and another one is "wall", "cell wall", and "plant cell walls" were supported for plant cell wall to be hotspots. Figure 5 shows the research trends for the topics of "Arabidopsis" and "plant cell wall" with the most articles were classified respectively from 1992 to 2016. "Pectins: Structure, biosynthesis, and oligogalacturonide-related signaling" by Ridley et al. (2001) was the most frequently cited article in plant cell wall research with $T C_{2016}$ of 876 . Authors described new methods that may be useful to study localized pectin structure in the plant cell wall. Pectin is biosynthesized and reviewed the biological activities and possible modes of action of pectic 
Table 3. Top 10 most productive countries

\begin{tabular}{lcccccccc}
\hline Country & $T P$ & $\begin{array}{r}T P R \\
(\%)\end{array}$ & $\begin{array}{c}I P R \\
(\%)\end{array}$ & $\begin{array}{c}C P R \\
(\%)\end{array}$ & $\begin{array}{r}F P R \\
(\%)\end{array}$ & $\begin{array}{r}R P R \\
(\%)\end{array}$ & $\begin{array}{r}S P R \\
(\%)\end{array}$ & $C_{2016}$ \\
\hline USA & 3,506 & $1(26)$ & $1(22)$ & $1(38)$ & $1(20)$ & $1(20)$ & $1(25)$ & 47 \\
Germany & 1,538 & $2(11)$ & $4(7.5)$ & $2(23)$ & $4(8.0)$ & $4(8.0)$ & $3(9.6)$ & 42 \\
UK & 1,444 & $3(11)$ & $5(6.6)$ & $3(23)$ & $5(7.4)$ & $5(7.3)$ & $2(12)$ & 51 \\
Japan & 1,441 & $4(11)$ & $2(11)$ & $6(11)$ & $2(9.4)$ & $2(9.4)$ & $4(8.3)$ & 32 \\
China & 1,370 & $5(10)$ & $3(10)$ & $5(11)$ & $3(9.1)$ & $3(9.3)$ & $13(1.5)$ & 16 \\
France & 1,278 & $6(9.5)$ & $6(6.3)$ & $4(19)$ & $6(6.8)$ & $6(6.8)$ & $7(4.6)$ & 39 \\
Canada & 556 & $7(4.1)$ & $8(2.9)$ & $7(7.7)$ & $7(2.9)$ & $7(2.9)$ & $8(3.9)$ & 32 \\
Australia & 470 & $8(3.5)$ & $11(2.3)$ & $9(7.0)$ & $12(2.4)$ & $12(2.4)$ & $9(2.4)$ & 32 \\
Spain & 462 & $9(3.4)$ & $14(2.0)$ & $8(7.6)$ & $11(2.5)$ & $11(2.4)$ & $14(1.3)$ & 32 \\
Italy & 454 & $10(3.4)$ & $10(2.6)$ & $12(5.7)$ & $9(2.6)$ & $9(2.6)$ & $10(1.8)$ & 29 \\
\hline
\end{tabular}

$T P$ : total articles, $T P R(\%)$ : total number of articles and the percentage of total articles; $I P R(\%)$ : rank and percentage of single country articles; $C P R(\%)$ : rank and percentage of internationally collaborative articles; $F P R(\%)$ : rank and the percentage of first author articles; $R P R(\%)$ : rank and the percentage of the corresponding authored articles; $S P R(\%)$; rank and the percentage of the single authored articles; $C P P_{2016}:$ citations per publication $\left(T C_{2016} / T P\right)$.

Table 4. Top 10 productive institutions

\begin{tabular}{|c|c|c|c|c|c|c|}
\hline Institute & $T P$ & $T P R(\%)$ & IPR (\%) & CPR (\%) & FPR $(\%)$ & $R P R(\%)$ \\
\hline $\begin{array}{l}\text { National Institute of } \\
\text { Agricultural Research } \\
\text { (INRA), France }\end{array}$ & 303 & $1(2.2)$ & $7(0.94)$ & $2(3.4)$ & $2(1.2)$ & $3(1.2)$ \\
\hline $\begin{array}{l}\text { National Center for } \\
\text { Scientific Research } \\
\text { (CNRS), France }\end{array}$ & 287 & $2(2.1)$ & $19(0.63)$ & $1(3.4)$ & $6(0.83)$ & $6(0.84)$ \\
\hline $\begin{array}{l}\text { Chinese Academy of } \\
\text { Sciences, China }\end{array}$ & 266 & $3(2.0)$ & $5(1.0)$ & $3(2.8)$ & $3(1.2)$ & $2(1.3)$ \\
\hline $\begin{array}{l}\text { Russian Academy of } \\
\text { Sciences, Russia }\end{array}$ & 261 & $4(1.9)$ & $1(2.6)$ & $14(1.4)$ & $1(1.7)$ & $1(1.7)$ \\
\hline $\begin{array}{l}\text { University of Tokyo, } \\
\text { Japan }\end{array}$ & 230 & $5(1.7)$ & $15(0.68)$ & $4(2.6)$ & $5(0.93)$ & $4(0.94)$ \\
\hline Cornell University, USA & 191 & $6(1.4)$ & $2(1.3)$ & $9(1.5)$ & $4(1.0)$ & $5(0.91)$ \\
\hline Purdue University, USA & 177 & $7(1.3)$ & $4(1.0)$ & $6(1.5)$ & $7(0.82)$ & $8(0.76)$ \\
\hline $\begin{array}{l}\text { University of California, } \\
\text { Berkeley, USA }\end{array}$ & 170 & $8(1.3)$ & $8(0.92)$ & $6(1.5)$ & $8(0.79)$ & $7(0.77)$ \\
\hline $\begin{array}{l}\text { University of Georgia, } \\
\text { USA }\end{array}$ & 158 & $9(1.2)$ & $9(0.89)$ & $14(1.4)$ & $11(0.71)$ & $14(0.64)$ \\
\hline $\begin{array}{l}\text { Spanish National } \\
\text { Research Council } \\
\text { (CSIC), Spain }\end{array}$ & 156 & $10(1.2)$ & $17(0.65)$ & $5(1.6)$ & $9(0.76)$ & $10(0.70)$ \\
\hline
\end{tabular}

$T P$ : total articles, $T P R(\%)$ : total number of articles and the percentage of total articles; $\operatorname{IPR}(\%)$ : rank and percentage of single institute articles; $C P R(\%)$ : rank and percentage of inter-institutionally collaborative article; $F P R(\%)$ : rank and the percentage of first author articles; $R P R(\%)$ : rank and the percentage of the corresponding authored articles; SPR (\%): rank and the percentage of the single authored articles. oligosaccharides referred to as oligogalacturonides (Ridley et al., 2001). The top five plant cell wall articles published by Martinez et al. (2008), Torney et al. (2007), Martin et al. (2008), Kaku et al. (2006), and Abad et al. (2008), affected a sharply increasing on plant cell wall research from 2007 (Figure 5). In addition, article entitled "Reactive oxygen species produced by NADPH oxidase regulate plant cell growth" by Foreman et al. (2003) was the most frequently cited Arabidopsis article which ranked $3^{\text {rd }}$ in both $T C_{2016}$ and $C_{2016}$ in plan cell research respectively. The number of articles related "Arabidopsis" had increased period from 1992 to 2004 and after that it showed fluctuated increase while studies on plant cell wall rose rapidly and have taken the lead in recent years especially from 2007 to 2016 . Therefore, in next researches, "Arabidopsis" will become the topic that concerned by researchers.

\section{Conclusion}

In total 16,972 plant cells-related papers published from 1992 to 2006 with 20 document types were found in SCIEXPANDED. English was the dominant language in these articles. Article was the most common document type considered. The citation history of selective articles showed that plant cell researches were given an increasing amount of attention over the period from 1992 to 2016 . Articles published before 2003 had higher annual citations per publication and articles need about one decade to reach a plateau on their citations per publication. Plant Physiology was the most popular journal listed in Web of Science category of plant sciences, which dominated plant cells research. USA contributed the most articles, followed by Germany and United Kingdom. The Institut National de la Recherche Agronomique (INRA) 
Table 5. Top 10 productive institutions

\begin{tabular}{lll}
\hline Rank & Rank & Articles \\
$\left(T C_{2016}\right)$ & $\left(C_{2016}\right)$ & \\
\hline
\end{tabular}

$1(1,446) \quad 13$ (76) Khvorova, A., Reynolds, A. and Jayasena, S.D., 2003. Functional siRNAs and miRNAs exhibit strand bias. Cell, 115(2), 209-216.

$2(1,393) \quad 2(155)$

Blokhina, O., Virolainen, E. and Fagerstedt, K.V., 2003. Antioxidants, oxidative damage and oxygen deprivation stress: a review. Annals of Botany, 91(2), 179-194.

Foreman, J., Demidchik, V., Bothwell, J.H.F., Mylona, P., Miedema, H., Torres, $3(1,078) 3(108) \quad$ M.A., Linstead, P., Costa, S., Brownlee, C., Jones, J.D.G., Davies, J.M. and Dolan, L., 2003. Reactive oxygen species produced by NADPH oxidase regulate plant cell growth. Nature, 422(6930), 442-446.

$4(1,005) 98$ (29) Chiu, W.L., Niwa, Y., Zeng, W., Hirano, T., Kobayashi, H. and Sheen, J., 1996. Engineered GFP as a vital reporter in plants. Current Biology, 6(3), 325-330.

Voinnet, O., Rivas, S., Mestre, P. and Baulcombe, D., 2003. Retracted: An 5 (995) 7 (93) enhanced transient expression system in plants based on suppression of gene silencing by the p19 protein of tomato bushy stunt virus. Plant Journal, 33 (5), 949956.

Boch, J., Scholze, H., Schornack, S., Landgraf, A., Hahn, S., Kay, S., Lahaye, T.,

6 (939) 1 (196) Nickstadt, A. and Bonas, U., 2009. Breaking the code of DNA binding specificity of TAL-type III effectors. Science, 326(5959), 1509-1512.

7 (876) 14 (72) Ridley, B.L., O'Neill, M.A. and Mohnen, D., 2001. Pectins: structure, biosynthesis, and oligogalacturonide-related signaling. Phytochemistry, 57(6), 929-967.

Bradley, D.J., Kjellbom, P. and Lamb, C.J., 1992. Elicitor-and wound-induced

8 (873) 495 (13) oxidative cross-linking of a proline-rich plant cell wall protein: a novel, rapid defense response. Cell, 70(1), 21-30.

Slowing, I.I., Trewyn, B.G., Giri, S. and Lin, V.S.Y., 2007. Mesoporous silica

9 (856) 5 (104) nanoparticles for drug delivery and biosensing applications. Advanced Functional Materials, 17(8), 1225-1236.

Alscher, R.G., Erturk, N. and Heath, L.S., 2002. Role of superoxide dismutases

10 (847) 4 (106) (SODs) in controlling oxidative stress in plants. Journal of Experimental Botany, 53(372), 1331-1341. 


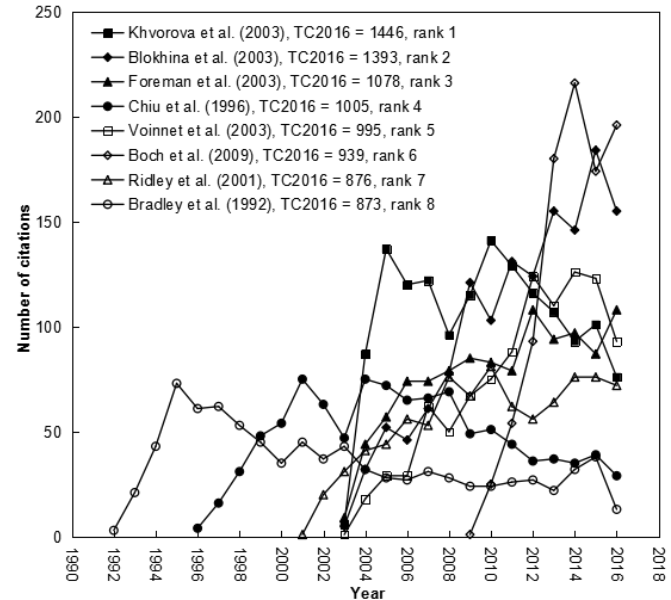

Figure 4. The top eight most frequently cited articles in the research field of plant cell.

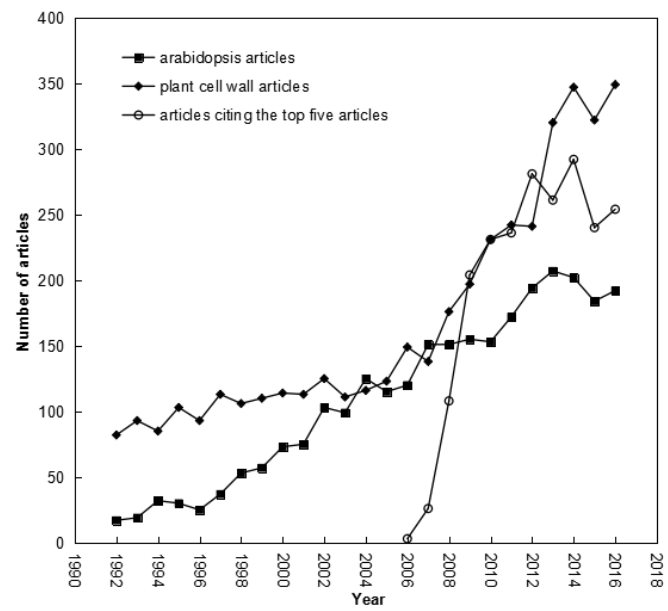

Figure 5. Comparison of the trends of plant cell related items.

in France was the most active in the plant cell research. University of Tokyo in Japan was the leading university in the world. Six of the top ten highly cited articles were also ranked in the top ten citations in the most recent year. Trends analysis showed that plant cell research mainly focuses on "Arabidopsis" and "plant cell wall".

\section{Conflict of Interest Statement}

No conflict of interest was reported by the authors.

\section{References}

Abad, P., Gouzy, J., Aury, J.M., Castagnone-Sereno, P., Danchin, E.G.J., Deleury, E., Perfus-Barbeoch, L., Anthouard, V., Artiguenave, F., Blok, V.C., Caillaud, M.C., Coutinho, P.M., Dasilva, C., De Luca, F., Deau, F., Esquibet, M., Flutre, T., Goldstone, J.V., Hamamouch, N., Hewezi, T., Jaillon, O., Jubin, C., Leonetti, P., Magliano, M., Maier, T.R., Markov,
G.V., McVeigh, P., Pesole, G., Poulain, J., Robinson-Rechavi, M., Sallet, E., Segurens, B., Steinbach, D., Tytgat, T., Ugarte, E., van Ghelder, C., Veronico, P., Baum, T.J., Blaxter, M., Bleve-Zacheo, T., Davis, E.L., Ewbank, J.J., Favery, B., Grenier, E., Henrissat, B., Jones, J.T., Laudet, V., Maule, A.G., Quesneville, H., Rosso, M.N., Schiex, T., Smant, G., Weissenbach, J. and Wincker, P., 2008. Genome sequence of the metazoan plant-parasitic nematode Meloidogyne incognita. Nature Biotechnology, 26(8), 909-915.

https://doi.org/10.1038/nbt.1482

Adl, S.M., Simpson, A.G.B., Lane, C.E., Luke, J., Bass, D., Bowser, S.S., Brown, M.W., Burki, F., Dunthorn, M., Hampl, V., Heiss, A., Hoppenrath, M., Lara, E., le Gall, L., Lynn, D.H., McManus, H., Mitchell, E.A.D., Mozley-Stanridge, S.E., Parfrey, L.W., Pawlowski, J., Rueckert, S., Shadwick, L., Schoch, C.L., Smirnov, A. and Spiegel, F.W., 2012. The revised classification of eukaryotes. Journal of Eukaryotic Microbiology, 59(5), 429-514. https://doi.org/10.1111/j.1550-7408.2012.00644.x

Alscher, R.G., Erturk, N. and Heath, L.S., 2002. Role of superoxide dismutases (SODs) in controlling oxidative stress in plants. Journal of Experimental Botany, 53(372), 1331-1341. https://doi.org/10.1093/jexbot/53.372.1331

Blokhina, O., Virolainen, E. and Fagerstedt, K.V., 2003. Antioxidants, oxidative damage and oxygen deprivation stress: a review. Annals of Botany, 91(2), 179-194. https://doi.org/10.1093/aob/mcf118

Boch, J., Scholze, H., Schornack, S., Landgraf, A., Hahn, S., Kay, S., Lahaye, T., Nickstadt, A. and Bonas, U., 2009. Breaking the code of DNA binding specificity of TAL-type III effectors. Science, 326(5959), 1509-1512. https://doi.org/10.1126/science.1178811

Boller, T. and Kende, H., 1979. Hydrolytic enzymes in the central vacuole of plant cells. Plant Physiology, 63(6), 1123-1132. https://doi.org/10.1104/pp.63.6.1123

Bradley, D.J., Kjellbom, P. and Lamb, C.J., 1992. Elicitor-and wound-induced oxidative cross-linking of a proline-rich plant cell wall protein: a novel, rapid defense response. Cell, 70(1), 21-30. https://doi.org/10.1016/0092-8674(92)90530-P

Burton, R.A. and Fincher, G.B., 2014. Plant cell wall engineering: applications in biofuel production and improved human health. Current Opinion in Biotechnology, 26, 79-84. https://doi.org/10.1016/j.copbio.2013.10.007

Cavalier-Smith, T., 2009. Kingdoms Protozoa and Chromista and the eozoan root of the eukaryotic tree. Biology Letters, 6 (3), 342-345. https://doi.org/10.1098/rsbl.2009.0948

Chen, H. and Ho, Y.S., 2015. Highly cited articles in biomass research: A bibliometric analysis. Renewable and Sustainable Energy Reviews, 49, 12-20. https://doi.org/10.1016/j.rser.2015.04.060

Chiu, W.L., Niwa, Y., Zeng, W., Hirano, T., Kobayashi, H. and Sheen, J., 1996. Engineered GFP as a vital reporter in plants. Current Biology, 6(3), 325-330. https://doi.org/10.1016/S0960-9822(02)00483-9

Chiu, W.T. and Ho, Y.S., 2007. Bibliometric analysis of tsunami research. Scientometrics, 73(1), 3-17. https://doi.org/10.1007/s11192-005-1523-1

Chuang, K.Y. and Ho, Y.S., 2015. An evaluation based on highly cited publications in Taiwan. Current Science, 108(5), 933941. 
Chuang, K.Y., Wang, M.H. and Ho, Y.S., 2011. High-impact papers presented in the subject category of water resources in the Essential Science Indicators database of the Institute for Scientific Information. Scientometrics, 87 (3), 551-562. https://doi.org/10.1007/s11192-011-0365-2

Chuang, K.Y., Olaiya, M.T. and Ho, Y.S., 2012. Bibliometric analysis of the Polish Journal of Environmental Studies (2000-11). Polish Journal of Environmental Studies, 21(5), 1175-1183.

Cosgrove, D.J., 2005. Growth of the plant cell wall. Nature Reviews Molecular Cell Biology, 6(11), 850-861. https://doi.org/10.1038/nrm1746

Elango, B. and Ho, Y.S., 2017. A bibliometric analysis of highly cited papers from India in Science Citation Index Expanded. Current Science, 112(8), 1653-1658. https://doi.org/10.18520/cs/v112/1653-1658

Foreman, J., Demidchik, V., Bothwell, J.H.F., Mylona, P., Miedema, H., Torres, M.A., Linstead, P., Costa, S., Brownlee, C., Jones, J.D.G., Davies, J.M. and Dolan, L., 2003. Reactive oxygen species produced by NADPH oxidase regulate plant cell growth. Nature, 422(6930), 442-446. https://doi.org/10.1038/nature01485

Fu, H.Z. and Ho, Y.S., 2013. Comparison of independent research of China's top universities using bibliometric indicators. Scientometrics, 96(1), 259-276. https://doi.org/10.1007/s11192-012-0912-5

Fu, H.Z. and Ho, Y.S., 2014. Top cited articles in adsorption research using Y-index. Research Evaluation, 23(1), 12-20. https://doi.org/10.1093/reseval/rvt018

$\mathrm{Fu}$, H.Z. and Ho, Y.S., 2015. A bibliometric analysis of the Journal of Membrane Science (1976-2010). The Electronic Library, 33(4), 698-713. https://doi.org/10.1108/EL-12-2013-0221

Fu, H.Z., Wang, M.H. and Ho, Y.S., 2012. The most frequently cited adsorption research articles in the Science Citation Index (Expanded). Journal of Colloid and Interface Science, 379(1), 148-156. https://doi.org/10.1016/j.jcis.2012.04.051

Fu, H.Z., Wang, M.H. and Ho, Y.S., 2013. Mapping of drinking water research: A bibliometric analysis of research output during 19922011. Science of the Total Environment, 443, 757-765. https://doi.org/10.1016/j.scitotenv.2012.11.061

Garfield, E., 1990. KeyWords Plus: takes you beyond title words. Part 2. Expanded journal coverage for Current Contents on Diskette, includes social and behavioral sciences. Current Contents, 33, 5-9.

Garfield, E., 1990. KeyWords Plus: ISI's breakthrough retrieval method. Part 1. Expanding your searching power on Current Contents on Diskette. Current Contents, 32, 5-9.

Gautheret, R.J., 1983. Plant tissue culture: A history. Botanical Magazine Tokyo, 96 (4), 393-410. https://doi.org/10.1007/BF02488184

Grasso, C., 1993. The Experimental Philosophy of Farming: Jared Eliot and the Cultivation of Connecticut. The William and Mary Quarterly, 50(3), 502-528. https://doi.org/10.2307/2947364

Guimarães, J.A. and Carlini, C.R., 2004. Most cited papers in Toxicon. Toxicon, 44(4), 345-359. https://doi.org/10.1016/j.toxicon.2004.05.002

Gunning, B.E.S. and Pate, J.S., 1969. "Transfer cells" plant cells with wall ingrowths, specialized in relation to short distance transport of solutestheir occurrence, structure, and development. Protoplasma, 68(1-2), 107-133.

https://doi.org/10.1007/BF01247900

Ho, Y.S., 2012. Top-cited articles in chemical engineering in Science Citation Index Expanded: A bibliometric analysis. Chinese Journal of Chemical Engineering, 20(3), 478-488. https://doi.org/10.1016/S1004-9541(11)60209-7

Ho, Y.S., 2014. Classic articles on social work field in Social Science Citation Index: a bibliometric analysis. Scientometrics, 98(1), 137-155. https://doi.org/10.1007/s11192-013-1014-8

Ho, Y.S. and Fu, H.Z., 2016. Mapping of metal-organic frameworks publications: A bibliometric analysis. Inorganic Chemistry Communications, 73, 174-182. https://doi.org/10.1016/j.inoche.2016.10.023

Ho, Y.S. and Kahn, M., 2014. A bibliometric study of highly cited reviews in the Science Citation Index Expanded. Journal of the Association for Information Science and Technology, 65(2), 372-385. https://doi.org/10.1002/asi.22974

Hussain, M.S., Fareed, S., Ansari, S., Rahman, M.A., Ahmad, I.Z. and Saeed, M., 2012. Current approaches toward production of secondary plant metabolites. Journal of Pharmacy \& Bioallied Sciences, 4 (1), 10-20. https://doi.org/10.4103/0975-7406.92725

Jin, H. and Martin, C., 1999. Multifunctionality and diversity within the plant MYB-gene family. Plant Molecular Biology, 41, 577-585.

https://doi.org/10.1023/A:1006319732410

Jones, L., Seymour, G.B. and Knox, J.P., 1997. Localization of pectic galactan in tomato cell walls using a monoclonal antibody specific to (1[-> ]4)-[beta]-D-galactan. Plant Physiology, 113(4), 1405-1412. https://doi.org/10.1104/pp.113.4.1405

Kaku, H., Nishizawa, Y., Ishii-Minami, N., Akimoto-Tomiyama, C., Dohmae, N., Takio, K., Minami, E. and Shibuya, N., 2006. Plant cells recognize chitin fragments for defense signaling through a plasma membrane receptor. Proceedings of the National Academy of Sciences of the United States of America, 103(29), 11086-11091. https://doi.org/10.1073/pnas.0508882103

Karley, A.J., Douglas, A.E. and Parker, W.E., 2002. Amino acid composition and nutritional quality of potato leaf phloem sap for aphids. Journal of Experimental Biology, 205(19), 3009-3018.

Khvorova, A., Reynolds, A. and Jayasena, S.D., 2003. Functional siRNAs and miRNAs exhibit strand bias. Cell, 115(2), 209216. https://doi.org/10.1016/S0092-8674(03)00801-8

Li, J.F., Zhang, Y.H., Wang, X.S. and Ho, Y.S., 2009a. Bibliometric analysis of atmospheric simulation trends in meteorology and atmospheric science journals. Croatica Chemica Acta, 82(3), 695-705.

Li, L.L., Ding, G.H., Feng, N., Wang, M.H. and Ho, Y.S., 2009b, Global stem cell research trend: Bibliometric analysis as a tool for mapping of trends from 1991 to 2006. Scientometrics, 80 (1), 39-58. https://doi.org/10.1007/s11192-008-1939-5

Li, Z. and Ho, Y.S., 2008. Use of citation per publication as an indicator to evaluate contingent valuation research. Scientometrics, 75(1), 97-110. https://doi.org/10.1007/s11192-007-1838-1 
Lin, C.L. and Ho, Y.S., 2015. A bibliometric analysis of publications on pluripotent stem cell research. Cell Journal(Yakhteh), 17 (1), 59-70. https://doi.org/10.22074/cellj.2015.512

Martin, F., Aerts, A., Ahren, D., Brun, A., Danchin, E.G.J., Duchaussoy, F., Gibon, J., Kohler, A., Lindquist, E., Pereda, V., Salamov, A., Shapiro, H.J., Wuyts, J., Blaudez, D., Buee, M., Brokstein, P., Canback, B., Cohen, D., Courty, P.E., Coutinho, P.M., Delaruelle, C., Detter, J.C., Deveau, A., DiFazio, S., Duplessis, S., Fraissinet-Tachet, L., Lucic, E., FreyKlett, P., Fourrey, C., Feussner, I., Gay, G., Grimwood, J., Hoegger, P.J., Jain, P., Kilaru, S., Labbe, J., Lin, Y.C., Legue, V., Le Tacon, F., Marmeisse, R., Melayah, D., Montanini, B., Muratet, M., Nehls, U., Niculita-Hirzel, H., Oudot-Le Secq, M.P., Peter, M., Quesneville, H., Rajashekar, B., Reich, M., Rouhier, N., Schmutz, J., Yin, T., Chalot, M., Henrissat, B., Kues, U., Lucas, S., Van de Peer, Y., Podila, G.K., Polle, A., Pukkila, P.J., Richardson, P.M., Rouze, P., Sanders, I.R., Stajich, J.E., Tunlid, A., Tuskan, G. and Grigoriev, I.V., 2008. The genome of Laccaria bicolor provides insights into mycorrhizal symbiosis. Nature, 452(7183), 88-92. https://doi.org/10.1038/nature06556

Martinez, D., Berka, R.M., Henrissat, B., Saloheimo, M., Arvas, M., Baker, S.E., Chapman, J., Chertkov, O., Coutinho, P.M., Cullen, D., Danchin, E.G.J., Grigoriev, I.V., Harris, P., Jackson, M., Kubicek, C.P., Han, C.S., Ho, I., Larrondo, L.F., de Leon, A.L., Magnuson, J.K., Merino, S., Misra, M., Nelson, B., Putnam, N., Robbertse, B., Salamov, A.A., Schmoll, M., Terry, A., Thayer, N., Westerholm-Parvinen, A., Schoch, C.L., Yao, J., Barabote, R., Nelson, M.A., Detter, C., Bruce, D., Kuske, C.R., Xie, G., Richardson, P., Rokhsar, D.S., Lucas, S.M., Rubin, E.M., Dunn-Coleman, N., Ward, M. and Brettin, T.S., 2008. Genome sequencing and analysis of the biomass-degrading fungus Trichoderma reesei (syn. Hypocrea jecorina). Nature Biotechnology, 26(5), 553-560. https://doi.org/10.1038/nbt1403

Mitani, Y., Oshima, Y., Mitsuda, N., Tomioka, A., Sukegawa, M., Fujita, M., Kaji, H. and Ohmiya, Y., 2017. Efficient production of glycosylated Cypridina luciferase using plant cells. Protein expression and purification, 133, 102-109. https://doi.org/10.1016/j.pep.2017.03.008

Morant, M., J $\phi$ rgensen, K., Schaller, H., Pinot, F., Mller, B.L., Werck-Reichhart, D. and Bak, S., 2007. CYP703 is an ancient cytochrome $\mathrm{P} 450$ in land plants catalyzing in-chain hydroxylation of lauric acid to provide building blocks for sporopollenin synthesis in pollen. The Plant Cell, 19(5), 1473-1487.

https://doi.org/10.1105/tpc.106.045948

Neuhaus, J.M. and Rogers, J.C. (1998) Sorting of proteins to vacuoles in plant cells. pp.127-144. In: Soll J (ed), Protein Trafficking in Plant Cells. Springer, Dordrecht. https://doi.org/10.1007/978-94-011-5298-3_7

Picknett, T. and Davis, K., 1999. The 100 most-cited articles from JMB. Journal of Molecular Biology, 293(2), 171-174. https://doi.org/10.1006/jmbi.1999.3148

Pollard, T.D. and Cooper, J.A., 2009. Actin, a central player in cell shape and movement. Science, 326(5957), 1208-1212. https://doi.org/10.1126/science.1175862

Raghavendra, A.S., Padmasree, K. and Saradadevi, K., 1994. Interdependence of photosynthesis and respiration in plant cells: interactions between chloroplasts and mitochondria. Plant Science, 97(1), 1-14. https://doi.org/10.1016/0168-9452(94)90101-5
Ridley, B.L., O’Neill, M.A. and Mohnen, D., 2001. Pectins: structure, biosynthesis, and oligogalacturonide-related signaling. Phytochemistry, 57(6), 929-967. https://doi.org/10.1016/S0031-9422(01)00113-3

Slowing, I.I., Trewyn, B.G., Giri, S. and Lin, V.S.Y., 2007. Mesoporous silica nanoparticles for drug delivery and biosensing applications. Advanced Functional Materials, 17(8), 12251236. https://doi.org/10.1002/adfm.200601191

Stals, H. and Inzé, D., 2001. When plant cells decide to divide. Trends in Plant Science, 6(8), 359-364. https://doi.org/10.1016/S1360-1385(01)02016-7

Tan, J., Fu, H.Z. and Ho, Y.S., 2014. A bibliometric analysis of research on proteomics in Science Citation Index Expanded. Scientometrics, 98(2), 1473-1490. https://doi.org/10.1007/s11192-013-1125-2

Thorpe, T.A., 2007. History of plant tissue culture. Molecular Biotechnology, 37(2), 169-180. https://doi.org/10.1007/s12033-007-0031-3

Torney, F., Trewyn, B.G., Lin, V.S.Y. and Wang, K., 2007. Mesoporous silica nanoparticles deliver DNA and chemicals into plants. Nature Nanotechnology, 2(5), 295-300. https://doi.org/10.1038/nnano.2007.108

van Kooten, O. and Snel, J.F.H., 1990. The use of chlorophyll fluorescence nomenclature in plant stress physiology. Photosynthesis Research, 25(3), 147-150. https://doi.org/10.1007/BF00033156

Vasil, I.K., 2008. A history of plant biotechnology: from the cell theory of Schleiden and Schwann to biotech crops. Plant Cell Reports, 27(9), 1423-1440. https://doi.org/10.1007/s00299-008-0571-4

Voinnet, O., Rivas, S., Mestre, P. and Baulcombe, D., 2003. Retracted: An enhanced transient expression system in plants based on suppression of gene silencing by the p19 protein of tomato bushy stunt virus. Plant Journal, 33(5), 949-956.

Voinnet, O., 2015. An enhanced transient expression system in plants based on suppression of gene silencing by the p19 protein of tomato bushy stunt virus (Retraction of Vol 33, Pg 949, 2003). Plant Journal, 83(4), 752.

Voinnet, O., Rivas, S., Mestre, P. and Baulcombe, D., 2015. An enhanced transient expression system in plants based on suppression of gene silencing by the $\mathrm{p} 19$ protein of tomato bushy stunt virus (Retraction of Vol 33, Pg 949, 2003). Plant Journal, 84(4), 846. https://doi.org/10.1111/tpj.13066

Wambu, E.W. and Ho, Y.S., 2016. A bibliometric analysis of drinking water research in Africa. Water SA, 42(4), 612-620. http://dx.doi.org/10.4314/wsa.v42i4.12

Wambu, E.W., Fu, H.Z. and Ho, Y.S., 2017. Characteristics and trends in global tea research: a Science Citation Index Expandedbased analysis. International Journal of Food Science \& Technology, 52(3), 644-651. http://dx.doi.org/10.1111/ijfs. 13317

Wang, C.C. and Ho, Y.S., 2016. Research trend of metaorganic frameworks: a bibliometric analysis. Scientometrics, 109(1), 481-513. https://doi.org/10.1007/s11192-016-1986-2

Wang, M.H., Fu, H.Z. and Ho, Y.S., 2011. Comparison of universities' scientific performance using bibliometric indicators. Malaysian Journal of Library \& Information Science, 16(2), 1-19. 
Wang, M.H., Yu, T.C. and Ho, Y.S., 2010. A bibliometric analysis of the performance of Water Research. Scientometrics, 84(3), 813-820.

https://doi.org/10.1007/s11192-009-0112-0

Yu, J.J., Wang, M.H., Xu, M. and Ho, Y.S., 2012. A bibliometric analysis of research papers published on photosynthesis: 19922009. Photosynthetica, 50(1), 5-14. https://doi.org/10.1007/s11099-012-0010-1

Zheng, M., Fu, H.Z. and Ho, Y.S., 2017. Research trends and hotspots related to ammonia oxidation based on bibliometric analysis. Environmental Science and Pollution Research,
24(25), 20409-20421.

https://doi.org/10.1007/s11356-017-9711-0

Zhong, R. and Ye, Z.H., 2007. Regulation of cell wall biosynthesis. Current Opinion in Plant Biology, 10(6), 564-572. https://doi.org/10.1016/j.pbi.2007.09.001

Zwieniecki, M.A., Melcher, P.J. and Holbrook, N.M., 2001. Hydrogel control of xylem hydraulic resistance in plants. Science, 291(5506), 1059-1062. https://doi.org/10.1126/science.1057175 